\title{
Evaluation of Alternative Preservation Treatments (Water Heat Treatment, Ultrasounds, Thermosonication and UV-C Radiation) to Improve Safety and Quality of Whole Tomato
}

\author{
Joaquina C. Pinheiro ${ }^{1}$ - Carla S. M. Alegria ${ }^{2}$ - Marta M. M. N. Abreu ${ }^{2}$. \\ Elsa M. Gonçalves ${ }^{2} \cdot$ Cristina L. M. Silva $^{3}$
}

Received: 3 August 2014 / Accepted: 13 January 2016 / Published online: 26 January 2016

(C) Springer Science+Business Media New York 2016

\begin{abstract}
Previously optimised postharvest treatments were compared to conventional chlorinated water treatment in terms of their effects on the overall quality of tomato ('Zinac') during storage at $10{ }^{\circ} \mathrm{C}$. The treatments in question were water heat treatment $\left(\mathrm{WHT}=40{ }^{\circ} \mathrm{C}, 30 \mathrm{~min}\right)$, ultrasounds (US $=45 \mathrm{kHz}, 80 \%, 30 \mathrm{~min}$ ), thermosonication (TS $=40{ }^{\circ} \mathrm{C}, 30 \mathrm{~min}, 45 \mathrm{kHz}, 80 \%$ ) and ultraviolet irradiation (UV-C: $0.97 \mathrm{~kJ} \mathrm{~m}^{-2}$ ). The quality factors evaluated were colour, texture, sensorial analysis, mass loss, antioxidant capacity, total phenolic content, peroxidase and pectin methylesterase enzymatic activities, and microbial load reduction. The results demonstrate that all treatments tested preserve tomato quality to some extent during storage at $10^{\circ} \mathrm{C}$. WHT, TS and UV-C proved to be more efficient on minimising colour and texture changes with the additional advantage of microbial load reduction, leading to a shelf life extension when compared to control trials. However, at the end of storage, with exception of WHT samples, the antioxidant activity and phenolic content of treated samples was low-
\end{abstract}

Cristina L. M. Silva

clsilva@porto.ucp.pt

1 MARE - Marine and Environmental Sciences Centre, Instituto Politécnico de Leiria, 2520-641 Peniche, Portugal

2 UEISTSA - Unidade Estratégica de Investigação e Serviços de Tecnologia e Segurança Alimentar, Instituto Nacional de Investigação Agrária e Veterinária, Estrada Paço do Lumiar, 22, 1649-038 Lisbon, Portugal

$3 \mathrm{CBQF}$ - Centro de Biotecnologia e Química Fina - Laboratório Associado, Escola Superior de Biotecnologia, Universidade Católica Portuguesa/Porto, Rua Arquiteto Lobão Vital, Apartado 2511, 4202-401 Porto, Portugal er than for control samples. Moreover, sensorial results were well correlated with instrumental colour experimental data. This study presents alternative postharvest technologies that improve tomato (Zinac) quality during shelf life period and minimise the negative impact of conventional chlorinated water on human safety, health and environment.

Keywords Water heat treatment · Ultrasounds . Thermosonication $\cdot$ Ultraviolet radiation · Tomato . Postharvest quality

\section{Introduction}

Tomato (Solanum lycopersicum) is a climacteric fruit with a rapid ripening and a short shelf life, which present serious limitations for its efficient handling and transportation (Klee and Giovannoni 2011). For these reasons, the optimization of the postharvest care of tomato fruit to obtain satisfactory quality is very important. If quality is maintained, market life can be extended, opening new opportunities and adding value to the fruit.

There have been numerous treatments applied to fresh tomato following harvest and prior to storage or marketing, in attempts to prolong storage life. These include various chemical, physical and biological treatments, including calcium applications (Wills et al. 1977), 1-methylcyclopropene (1-MCP) (Su and Glubber 2012), modified atmosphere (Mathooko 2003), edible coatings (Dávila-Aviña et al. 2011), and antagonists (Mari et al. 1996). While many of these treatments have shown some effectiveness in reducing decay, maintaining quality, and/or enhancing desirable characteristics, few have been widely used commercially given the process complexity and the high costs involved. 
However, the most promising of the different emerging technologies to maintain the tomato quality appear to be water heat treatment (WHT) (Pinheiro et al. 2014; Pinheiro et al. 2012a), ultrasounds (US) (Pinheiro et al. 2012b), thermosonication (TS, combination of sonication and heat) (Pinheiro et al. 2012c) and ultraviolet radiation (UV-C) (Pinheiro et al. 2010). These treatments intend to eliminate unwanted bacterial load, ensure high nutritional and sensory quality, as well as extend its shelf life and storability. Moreover, these postharvest treatments were established to achieve other important requirements, such as minimising environment hazards, addressing consumer-oriented concerns (health promoting compounds, food safety) and low treatment cost, which represent additional arguments to the widespread use of these technologies.

The aim of this study was to evaluate and compare the effects of postharvest treatments previously optimised: water heat treatment (WHT), ultrasounds (US), thermosonication (TS) and ultraviolet radiation (UV-C) on physical (colour, firmness, mass loss), biochemical (enzymatic activities: peroxidase and pectin methylesterase), nutritional (antioxidants and total phenolic content) and sensorial quality (colour and degree of deterioration rating), and microbial load (mesophylic and yeasts and moulds load) on tomato ('Zinac') fruit, during 30 days of storage at $10{ }^{\circ} \mathrm{C}$. Moreover, this study intends to select one treatment that contributes to delaying ripening deterioration changes, minimising the microbial development while maintaining sensorial quality.

\section{Materials and Methods}

\section{Plant Material}

Tomatoes (Solanum lycopersicum 'Zinac') were obtained from a commercial greenhouse Carmo and Silvério in centre west of Portugal. Fruit were harvested at mature green stage and their classification was performed through external colour, according to USDA standard tomato colour classification (USDA 1991). Tomatoes were selected with uniform colour and size, and without bruises or signs of infection.

\section{Treatments}

Tomato fruit were divided into five groups of ca. $15 \mathrm{~kg}$ each: either washed with chlorinated water (HIPO - Ctr samples) or treated with alternative treatments: water heat treatment (WHT), singular ultrasounds (US), ultrasounds combined with heat (thermosonication, TS) and ultraviolet radiation (UV-C).

\section{Chlorinated Water Treatment}

A chlorinated water treatment $\left(150 \mathrm{ppm}\right.$ at $5{ }^{\circ} \mathrm{C}, \mathrm{pH} 6.5$ during 2 min) (Bartz et al. 2001) as decontamination methodology was used as control treatment (Ctr) during storage period at $10{ }^{\circ} \mathrm{C}$.

\section{WHT, US and TS Treatments}

The WHT, US and TS treatments were carried out in a water bath (Elma Transsonic Cleaning baths-multiplefrequency units-Elma $\mathrm{GmbH} \& \mathrm{Co}$, Singen, Germany) with $45 \mathrm{~L}$ capacity, and using previously optimised conditions. For the WHT tomato samples were subjected to a temperature of $40 \pm 0.5{ }^{\circ} \mathrm{C}$ during $30 \mathrm{~min}$ (Pinheiro et al. 2012a); for the US, a constant US frequency of $45 \mathrm{kHz}$ and power of $80 \%$ during $30 \mathrm{~min}$ was applied on tomato samples (Pinheiro et al. 2012b); and for the TS, a combination of US and WHT conditions were applied $\left(45 \mathrm{kHz}, 80 \%, 40{ }^{\circ} \mathrm{C}\right.$ during $30 \mathrm{~min}$ ) (Pinheiro et al. 2012c). After treatments, samples were cooled and paper dried for excess water removal.

\section{UV-C Treatment}

The UV-C samples treatments were conducted in a closed box $(43 \mathrm{~cm}(w) \times 50 \mathrm{~cm}(l) \times 24 \mathrm{~cm}(h))$ equipped with two germicidal lamps (TUV 15 W/G15T8, Philips, Holland) emitting at $254 \mathrm{~nm}$ and placed $10 \mathrm{~cm}$ above tomato fruit. The box was covered with aluminium foil to promote a homogeneous light distribution. Prior to use, UV-C lamps were stabilised by turning them on for $15 \mathrm{~min}$. Whole tomatoes were placed in a single layer on the illumination area at the fixed distance and rotated manually $\left(180^{\circ}\right)$ in order to ensure total UV exposure. The tested UV-C intensity was measured by a photoradiometer (DELTA OHM LP9021 UVC, Padova, Italy), giving corresponding doses of $0.97 \mathrm{~kJ} \mathrm{~m}^{-2}$ after exposure time of $3 \mathrm{~min}$, as previously optimised by Pinheiro et al. (2010).

A physical-chemical and microbial characterisation of tomato fruit after washing with chlorinated water (Ctr samples) and immediately after treatments (WHT, US, TS and UV-C) was performed to provide a baseline comparison to the treatments effects.

After treatments, all samples: control (Ctr) and treated (WHT, US, TS and UV-C) were stored at appropriate storage temperature, as previously optimised by Pinheiro et al. (2013): $10 \pm 0.5^{\circ} \mathrm{C}$ and $90 \pm 1 \%$ RH (S600 Pharma, Fitoclima, Aralab - Equipamentos de Laboratório e Electromecânica Geral Lda., Portugal) during 30 days. Temperature and humidity were monitored with a HygroLog data logger (Rotronic AG, Bassersdorf, Switzerland). 


\section{Methods}

\section{Colour}

Tomato colour was evaluated using a tristimulus colorimeter (Konica Minolta Chroma Meter, CR-300, Konica Minolta, Inc., Tokyo, Japan). The instrument was calibrated using a white standard tile $\left(L^{*}=97.10, a^{*}=0.19, b^{*}=1.95\right)$, using the illuminate $\mathrm{C}$ (10th observer). A CIE colour space co-ordinates, $L^{*} a^{*} b^{*}$ values, was determined. $L^{*}$ values represent the luminosity of samples $(0=$ black to $100=$ white $), a^{*}$ and $b^{*}$ values indicate the variation of greenness to redness ( -60 to $+60)$ and blueness to yellowness $(-60$ to +60$)$, respectively. From the coordinates CIELab, hue value $\left({ }^{\circ} h=\operatorname{arctg}\left(b^{*} / a^{*}\right)\right)$ was calculated. Sixteen measurements were taken from four fruits for each treatment.

\section{Texture}

Texture was determined by a penetration test with a Texture Analyser (TA.HDi, Stable Microsystem Ltd, Godalming, UK), using a $50 \mathrm{~N}$ load cell and a stainless steel cylinder probe with a $2 \mathrm{~mm}$ diameter. The penetration test was performed at $3 \mathrm{~mm} \mathrm{~s}^{-1}$ of speed and at $7.5 \mathrm{~mm}$ of penetration distance. Force-distance curves were recorded and firmness (maximum peak force, $\mathrm{N}$ ) was used as indicator of texture parameter. Firmness was measured after holding the tomato at room temperature for $2 \mathrm{~h}$, to avoid storage temperature effects on determination. Sixteen measurements were taken from four fruits for each treatment.

\section{Sensorial Analysis}

Sensorial analysis was performed using an analyticaldescriptive test to discriminate the sensory quality attributes of $\mathrm{Ctr}$ and treated samples along refrigerated storage. A panel of 8-10 trained judges (members of UEISTSA), who met the basic requirements of sensory sensitivity according to ISO 8586-1 (1993), in adequate conditions compliant to ISO 13299 (1995), identified and distinguished the sensory attributes of colour, global acceptability and deterioration index (visual evaluation) of fresh tomato fruit, using numeric rating scales as follows:

Colour rating system: $1=$ green $(0 \%$ red $) ; 2=$ breaker $(<10 \%$ red $) ; 3=$ turning $(10 \%<$ red $<30 \%) ; 4=$ pink $(30 \%<\operatorname{red}<60 \%) ; 5=\operatorname{red}(60 \%<\operatorname{red}<90 \%)$ and $6=\operatorname{red}(>90 \%$ red $)$.

Global acceptability rating system: $1=$ highly acceptable; $2=$ moderately acceptable; $3=$ medium acceptable (consumer limit); $4=$ moderately unacceptable; $5=$ unacceptable.

Degree of deterioration rating system: $0=$ absent; $1=$ very slight; 2 = moderate; $3=$ severe.
Moderate to severe deteriorated fruit are not commercialised and represent disorders affecting from 25 to $50 \%$ (anchor 2 ) and over $50 \%$ of fruit surface (anchor 3 ), respectively.

Panellists were asked to evaluate samples during storage, scoring the difference in perceived intensity between treated and $\mathrm{Ctr}$ samples with respect to each attribute.

\section{Mass Loss}

Mass loss was measured by Van Dijk et al. (2006) method. A batch constituted by three fruits per treatment was weighted. After weighting, tomatoes were put back to original storage conditions. The mass loss was calculated relative to the mass at day zero $(t=0)$.

(\%) Mass loss $=\frac{M_{0}-M_{t}}{M_{0}} \times 100$

where $M_{0}$ is the average mass of the first batch at day 0 , and $M_{t}$ is the average mass of the same batch at day $t$. Two replicates were carried out.

This parameter could be used to define fruit quality due to its impact on the tissue which becomes dull and very soft when mass loss is high.

\section{Antioxidant Activity}

Antioxidant activity was analysed with the 2,2'-azino-bis(3ethylbenzothiazoline-6-sulphonic acid) (ABTS) method as described by Re et al. (1999). This stable radical cation was analysed by mixing $10 \mathrm{~mL}$ of a $7 \mu \mathrm{mol} / \mathrm{L}$ ABTS solution with $10 \mathrm{~mL}$ of a $2.45 \mu \mathrm{mol} / \mathrm{L} \mathrm{K}_{2} \mathrm{~S}_{2} \mathrm{O}_{8}$ solution. After $24 \mathrm{~h}$ at room temperature in the darkness, the ABTS stock solution was ready to use. An ABTS working solution was prepared daily by diluting the ABTS stock solution with ethanol to an absorbance between 0.680 and 0.720 at $734 \mathrm{~nm}$ in a Pye Unicam UV4-100 UV/VIS spectrophotometer (Unicam Limited, Cambridge, UK). Thirty microliters of extract were mixed with $3 \mathrm{~mL}$ of ABTS at $30{ }^{\circ} \mathrm{C}$ during $7 \mathrm{~min}$. Trolox solutions (150-2500 $\mu \mathrm{mol} / \mathrm{L})$ were used for constructing a regression line. Results were expressed as micromole Trolox equivalents of antioxidant capacity ( $\mu \mathrm{mol}$ TEAC $100 \mathrm{~g}^{-1}$ ) of fresh fruit. Six measurements for each sample were obtained.

\section{Total Phenolic Content}

Total phenolic were determined using the Folin-Ciocalteau reagent (Singleton and Rossi 1965). Five tomato fruits were chopped and blended for 2 min until uniform size. Samples (10 g) were homogenised in $70 \%$ aqueous methanol $(10 \mathrm{ml})$, 
using a yellow line DI 25 basic polytron (IKA-Labortechnik, Stauten, Germany), centrifuged (Sorvall RC-5, rotor SS34, DuPont, Wilmington, USA) at 19,000 rpm for $20 \mathrm{~min}$ at $4{ }^{\circ} \mathrm{C}$, and the supernatant was collected. One hundred microlitres of supernatant was mixed with $5 \mathrm{~mL}$ of FolinCiocalteau $(1 / 10, v / v)$ and $4 \mathrm{~mL}$ of $\mathrm{Na}_{2} \mathrm{CO}_{3}(7.5 \%, w / v)$. The mixture was placed in a water bath $\left(45^{\circ} \mathrm{C}\right.$ for $\left.15 \mathrm{~min}\right)$ and the absorbance measured at $765 \mathrm{~nm}$ in the spectrophotometer, using gallic acid as a standard. Results were expressed as milligramme gallic acid equivalents (mg GAE $100 \mathrm{~g}^{-1}$ ) of fruit mass. Six measurements for each sample were carried out.

\section{Enzymatic Activity}

Pectin methylesterase (PME) activity was determined by a spectrophotometric procedure optimised by Pinheiro et al. (2012d). Four tomato fruits were chopped and blended for 2 or $3 \mathrm{~min}$. Ten grams of blended tomato were homogenised with $90 \mathrm{~mL}$ of cold $1.5 \mathrm{M} \mathrm{NaCl}$, using a yellow line DI 25 basic polytron (IKA-Labortechnik, Stauten, Germany). The mixture was centrifuged at 19,000 rpm for $20 \mathrm{~min}$ at $4{ }^{\circ} \mathrm{C}$. Then, the supernatants were filtered and adjusted to the desired pH (CrisonMicro pH 2001, Crison Instruments, Barcelona, Spain) with $\mathrm{NaOH} 0.1$ and $0.01 \mathrm{~N}$. The standard reaction mixture contained $0.5 \%$ pectin from citrus fruits (Sigma Aldrich, $2 \mathrm{~mL}$ ), $0.01 \%$ cresol red in sodium phosphate buffer at $0.003 \mathrm{M}$ and $\mathrm{pH} 8.8(0.150 \mathrm{~mL})$, enzyme extract and water $(0.05$ and $0.800 \mathrm{~mL}$, respectively). The reaction mixture was incubated at $30{ }^{\circ} \mathrm{C}$ and the activity was measured at $573 \mathrm{~nm}$ during $1 \mathrm{~min}$.

Peroxidase (POD) activity was determined as described in Yahia et al. (2007) with some modifications. Four tomato fruits were chopped and blended for 2 or $3 \mathrm{~min}$. Ten grams of blended tomato were homogenised with $50-\mathrm{mL}$ sodium phosphate buffer (0.05 $\mathrm{M} \mathrm{pH} \mathrm{7.0)} \mathrm{and} \mathrm{centrifuged} \mathrm{at} \mathrm{19,}$ $000 \mathrm{rpm}$ for $20 \mathrm{~min}$ at $4{ }^{\circ} \mathrm{C}$. The reaction medium contained $2.855 \mathrm{~mL}$ sodium phosphate buffer $(0.05 \mathrm{M}, \mathrm{pH} 6.0), 45 \mu \mathrm{l}$ guaiacol ( $1 \%), 40 \mu \mathrm{H}_{2} \mathrm{O}_{2}(0.3 \%)$, and $60 \mu$ lenzyme extract. The absorbance was recorded at $470 \mathrm{~nm}$ with the spectrophotometer.

Both enzymatic activities (POD and PME) were expressed as activity units per $100 \mathrm{~g}$ of tomato, and the results were normalised in regard to the corresponding fresh tomato activity $(\%-P / P 0 \times 100$, where $P 0$ is the initial enzymatic activity at initial time and $P$ is the activity at time $t$ ). Final enzyme activities were determined from the average of four independent measurements from four fruits each.

\section{Microbial Count}

Measurements of total mesophylic counts were performed according to ISO 4833 (2003). Ten grams of sample were mixed with $90 \mathrm{~mL}$ peptone saline solution in a sterile stomacher bag and homogenised for $1 \mathrm{~min}$ using a Stomacher. Dilutions were made in peptone water as needed for plating. Plate count agar was used as the media for total mesophylic counts and incubated at $30{ }^{\circ} \mathrm{C}$ for 3 days. Yeast and mould (Y\&M) were determined according to NP 3277 (1987), using Rose Bengal Chloramphenicol Agar, surface inoculation and incubated at $25{ }^{\circ} \mathrm{C}$ during 5 days. A total of three independent measurements were taken per sample and results were expressed as $\log _{10} \mathrm{cfu}^{-1}$.

\section{Data Analysis}

Data were subjected to analysis of variance (two-way ANOVA) using Statistica v.7.0 (Statsoft, 2004) to assess treatments and storage period effects on tomato quality. Tukey test was used to determine the significance of differences between means $(p<0.05)$.

\section{Results and Discussion}

\section{Colour}

Colour is probably one of the most important attributes influencing tomato overall quality, as it affects consumer perception and acceptance. A number of physical-chemical changes occur when tomato progress from the mature green to red maturity stage. The most obvious change is the external colour, which is associated with chlorophyll loss and lycopene accumulation due to ripening (Saltveit 2005).

Only the luminosity did not differ significantly $(p>0.05)$ after treatments (ca. 48-49). Treatments with heat application (WHT and TS) lead to a significant $(p<0.05)$ loss of tomato green colour (increase of $a^{*}$ value) in comparison with control samples $(-13.1 \pm 1.0)$. On the other hand, the colour of US and UV-C samples was similar $(p>0.05)$ to control samples. These treatments, therefore, did not affect the initial tomato colour characteristics.

Figure 1a presents the behaviour of tomato $L^{*}$ parameter during storage at $10{ }^{\circ} \mathrm{C}$. As expected, during storage, $L^{*}$ values decrease, reflecting an increase of tomato darkening due to carotenoid synthesis (Yahia et al. 2007). Only on UVC samples an increase of $L^{*}$ value was observed. However, only in Ctr samples a marked reduction of $L^{*}$ value was observed from days 4 to 20 , reaching the lowest value of all samples $\left(L^{*}=42.3\right)$. This fact indicates that all treatments lead to a delay of tomato colour changes.

The impact of treatments on greenness (lower $a^{*}$ value) and redness (higher $a^{*}$ value) of tomato fruit can be observed in Fig. 1b. The Ctr sample showed a fast red 
Fig. 1 Changes in $L^{*}$ (a) and $a^{*}$ (b) colour parameters of control (Ctr) and treated (US, WHT, TS, UV-C) stored tomato at $10{ }^{\circ} \mathrm{C}$. Vertical bars represent $95 \%$ of confidence intervals
(A)

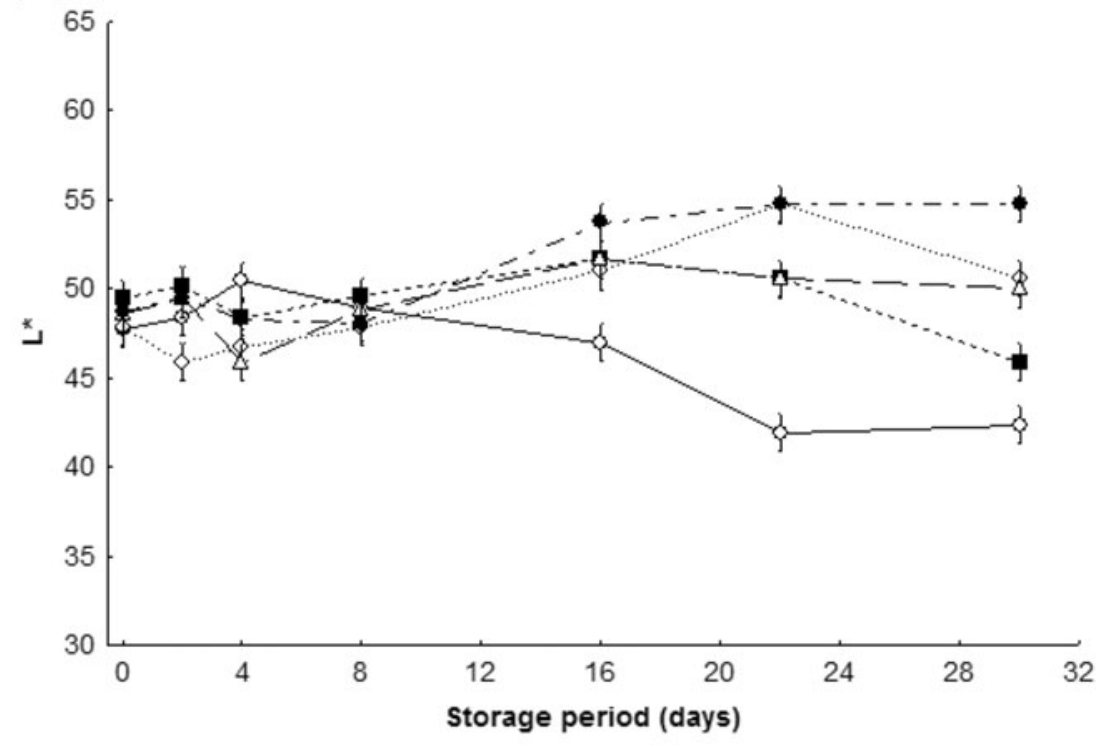

호 Ctr 푸 US 포. WHT 호 TS 호 UV-C

(B)

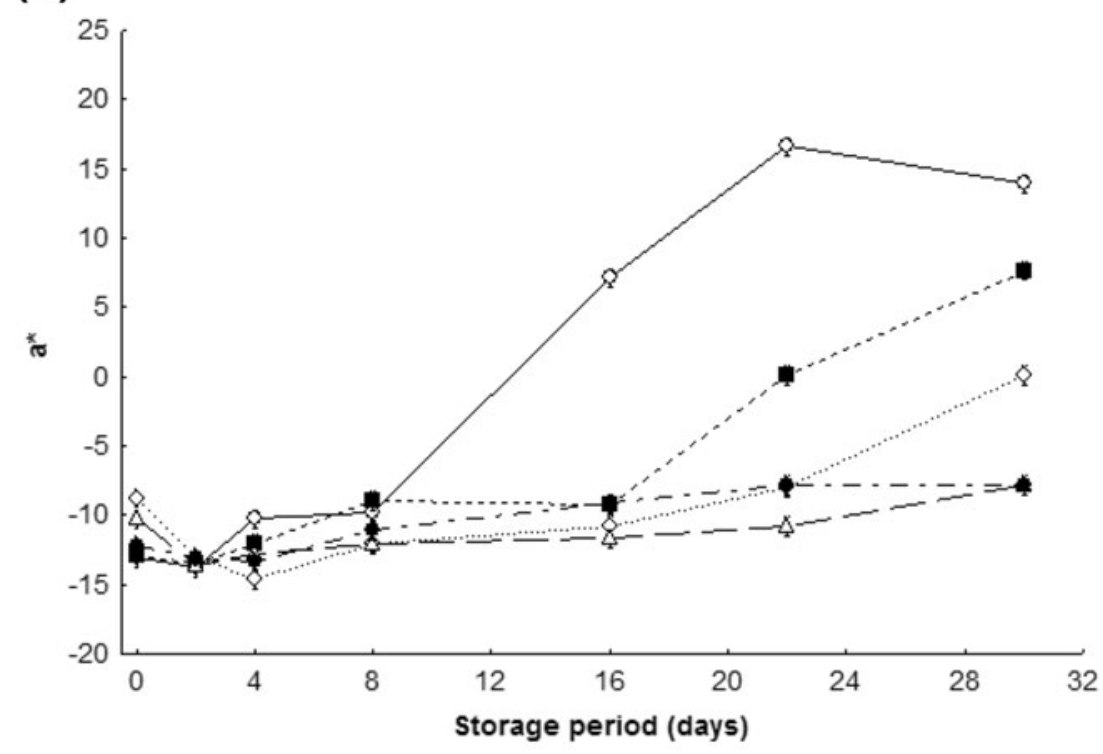

쪼 Ctr 푸 US 포. WHT 조 TS 호 UV-C colour development (higher $a^{*}$ ) compared with treated samples (WHT, US, TS and UV-C). Moreover, from days 8 till 22, the $a^{*}$ value of Ctr samples reached a maximum of 16.6. Similar behaviour was reported by Guillén et al. (2006) on different tomato cultivars ('Cherry' and 'Daniela', round; 'Patrona', pear-type; 'Raf', lobular) and two maturity stages (S1 and S2), during 28 days storage at $10{ }^{\circ} \mathrm{C}$.

The US and WHT samples showed a pronounced increase of $a^{*}$ value from day 16 until the end of storage, attaining 7.6 and 0.09 , respectively. The TS treatment that combines the synergistic effect of heat and US, showed the same beneficial effect as UV-C radiation, and both treatments delay red colour development and exhibited the lowest final $a^{*}$ value $(-7.8)$.

A study on red bell pepper (Alexandre et al. 2011) demonstrated that thermosonication at $50^{\circ} \mathrm{C} 35 \mathrm{kHz} 2$ min retained sample colour better than US treatments. Vicente et al. (2005) observed also that peppers treated with UV-C radiation had higher hue values than $\mathrm{Ctr}$ samples stored at $10{ }^{\circ} \mathrm{C}$. 


\section{Texture}

Firmness is another important quality-related attribute in tomato fruit, and may be considered as a final quality index by which the consumer decides to purchase the product. The major problem concerning tomato firmness is related to tissue softening which usually involves one of two mechanisms: mass loss with turgor loss, or a result of enzymatic activity leading to structural changes in the principal cell wall components (cellulose, hemicellulose and pectin) (Alia-Tejacal et al. 2007). Therefore, any treatment able to delay fruits softening is potentially helpful to extend postharvest shelf life and maintain product quality.

After washing with chlorinated water, tomatoes had an initial firmness of $12.5 \pm 1.2$. Pinheiro et al. (2013) reported a similar value $(12.8 \pm 0.3 \mathrm{~N})$ for tomatoes of the same cultivar and of the same maturity stage.

Immediately after US, WHT, TS and UV-C treatments, no significant $(p>0.05)$ firmness changes were observed, and only a slight increase of ca. $6 \%$ was observed after US, TS and UV-C, while WHT samples firmness remained unchanged, compared to control.

Abreu et al. (2011) found a firming effect in Rocha pear after treatment at $35^{\circ} \mathrm{C}$ during $20 \mathrm{~min}$. Possible reasons for firmness increase after heat treatment can be due to the activation of pectin methylesterase (PME) and subsequent formation of calcium pectates, or the heat changes effects on protein metabolism by suspending the synthesis of housekeeping proteins to produce heat-shock proteins (Brodl 1989).

Changes in stored tomato firmness at $10{ }^{\circ} \mathrm{C}$ are shown in Fig. 2. It is evident that all samples present a gradual and pronounced softening along the first 8 storage days. The firmness reduction was more pronounced for $\mathrm{Ctr}$ and US samples, ca. 31 and $26 \%$, respectively, compared to initial value. After the 16th day, no statistically significant differences $(p>0.05)$

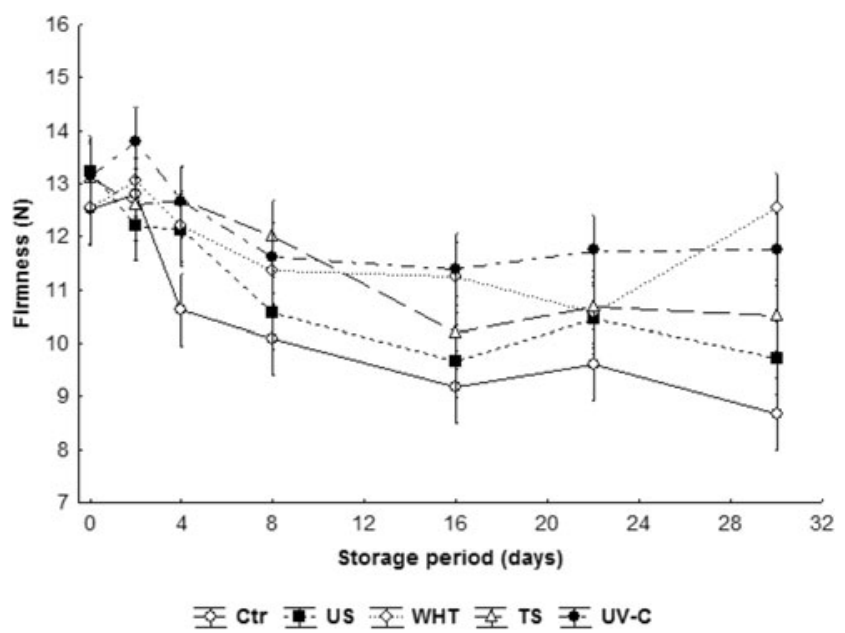

Fig. 2 Changes in firmness (N) of control (Ctr) and treated (US, WHT, TS, UV-C) stored tomato at $10{ }^{\circ} \mathrm{C}$. Vertical bars represent $95 \%$ of confidence intervals in firmness of Ctr, US and TS were found. Moreover, the firmness of UV-C samples did not change from day 8 . Both samples of UV-C and WHT presented the highest maximum force at the end of storage (more 30 and $26 \%$, respectively, comparing with the $\mathrm{Ctr}$ ), revealing an advantage of these technologies for delaying tomato softening during postharvest.

Previous studies demonstrated the benefits of UV-C treatment to delay fruits ripening and maintain postharvest firmness, such as in Kent and Seascape cultivars of strawberry treated with UV-C doses of 1 and $4.1 \mathrm{~kJ} \mathrm{~m}^{-2}$, respectively (Barka et al. 1999; Pan et al. 2004). Barka et al. (2000) suggested that delay of softening on UV-C tomato would be due to lower cell wall degradation, and cell wall degrading enzymes may be targets of UV-C radiation.

\section{Sensorial Analysis}

Figure 3 presents sensorial results of colour, global acceptability and deterioration index of $\mathrm{Ctr}$ and treated tomato samples, immediately after treatment and during storage. Immediately after treatments, no significant differences $(p>0.05)$ were detected in fruit colour perception between Ctr and treated samples, indicating good acceptability (score 1) and undetectable deterioration (score 0 ). Comparing sensorial analysis with previous experimental colour parameter ( $a^{*}$ value) a good and significant correlation $\left(R^{2}=0.93, p=0.00\right)$ was obtained, as shown in Fig. 3d.

From day 8 of storage, the Ctr samples were the less preferred in terms of global acceptability (Fig. 3), due to firmness and mass loss changes. Also, all treated samples were characterised by a trained panel as better fruit during storage. The UV-C and TS-treated samples presented the lowest score $(1.9=$ moderately acceptable), revealing the consumer preference at the end of storage. The global acceptability behaviour correlates well with fruit colour $\left(R^{2}=0.95, p=0.00\right)$.

Regarding deterioration index (Fig. 3c), until the first four storage days, no significant difference $(p>0.05)$ was detected in all samples. After this period, the Ctr samples started to be negatively rated, becoming very slight to moderate (25$50 \%$ ), defined as consumer limit.

\section{Mass Loss}

Tomato mass loss is affected by several pre and postharvest factors, such as harvest date and storage temperature (AliaTejacal et al. 2007). The influence of treatments and storage period on tomato mass loss is shown in Fig. 4. All treatments present an increase of tomato mass loss during storage at $10{ }^{\circ} \mathrm{C}$. The rate of mass loss per day of control sample was $0.20 \%$ and differs significantly $(p<0.05)$ from other samples. Treatments of US and TS have rate values per day of 0.17 and $0.14 \%$, respectively, and both WHT and UV-C samples a rate of $0.15 \%$. 
Fig. 3 Changes in sensorial colour a global acceptability b and deterioration index $\mathbf{c}$ of (Ctr) and treated (US, WHT, TS, UVC) stored tomato at $10{ }^{\circ} \mathrm{C}$. Graph of correlation between sensorial colour and objective colour d Vertical bars represent $95 \%$ of confidence intervals
(A)

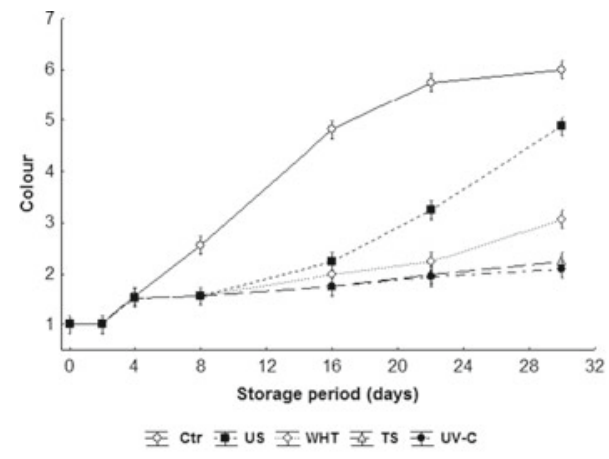

(C)

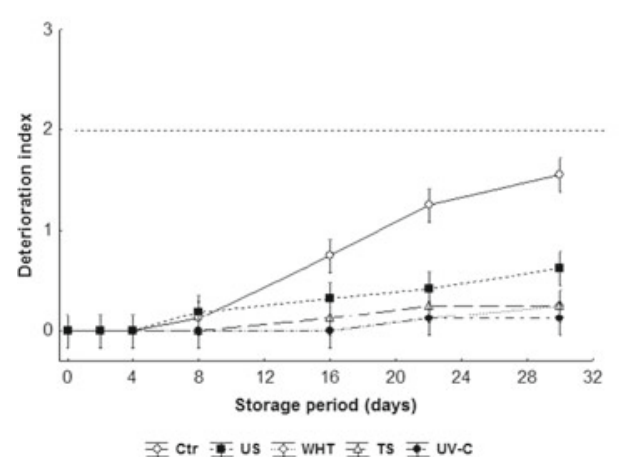

(B)

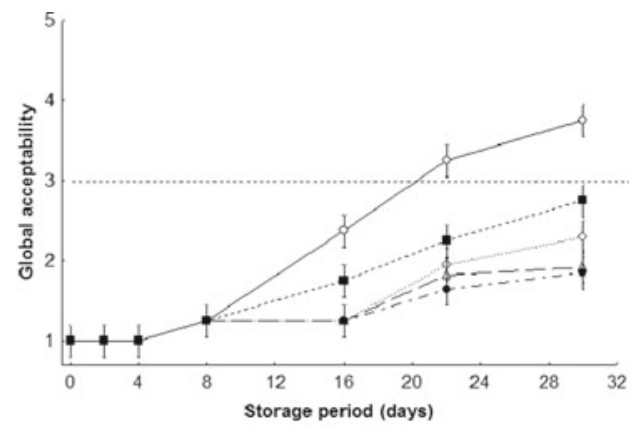

(D)

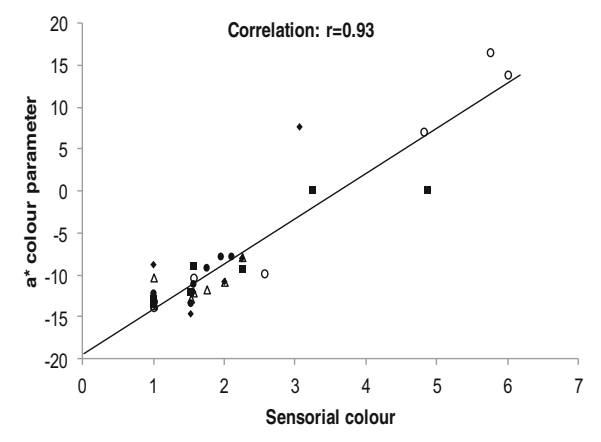

The increase of mass loss observed on WHT and TS was lower than observed in other samples. This increase might be a response to the higher temperature and long-time treatment that increase the vapour pressure deficit and the water loss of fruit (Assi 2004). However, treatments such as UV-C, WHT and TS lead to the lowest value of mass loss $(4.4 \%, p>0.05)$ at the end of storage. The low mass losses observed for WHT samples during storage had beneficial effects mainly on the

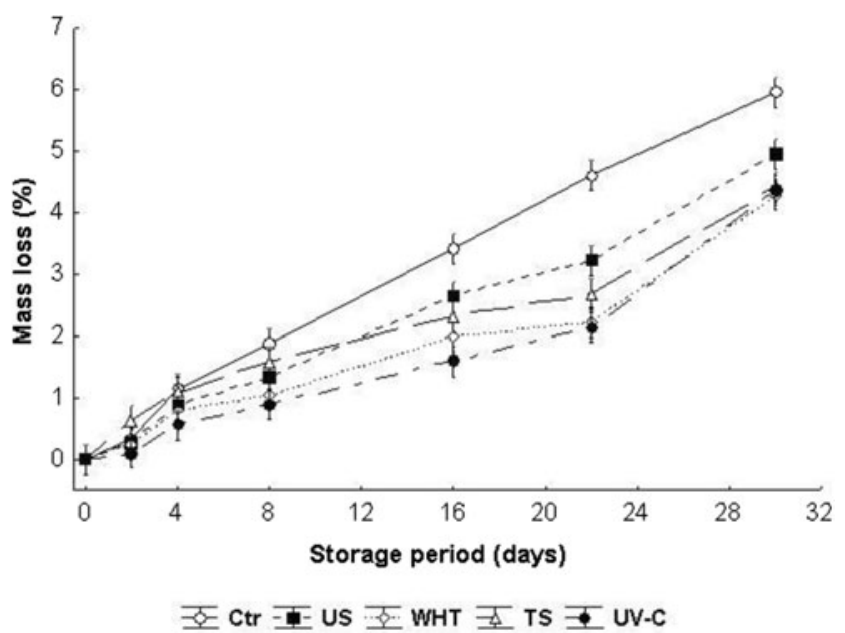

Fig. 4 Changes in mass loss (\%) of control (Ctr) and treated (US, WHT, $\mathrm{TS}, \mathrm{UV}-\mathrm{C})$ stored tomato at $10{ }^{\circ} \mathrm{C}$. Vertical bars represent $95 \%$ of confidence intervals appearance of the fruit. Opposite results were obtained by Forney (1995), that after testing different heat treatment conditions $\left(25-52{ }^{\circ} \mathrm{C}, 1-40 \mathrm{~min}\right)$ on broccoli, a higher rate of average mass loss per day (ca. $6 \%$ than observed in Ctr sample $(4.6 \%))$ was observed. In strawberries, hot air treatment at $45{ }^{\circ} \mathrm{C}$ during $3 \mathrm{~h}$ led to increased mass losses (more $1 \%$ than in untreated fruit) (Vicente et al. 2002).

With the exception of Ctr sample, US treatment was the least effective on reducing tomato mass loss, reaching a value of $5 \%$ at the end of storage. Along 30 days of storage at $10{ }^{\circ} \mathrm{C}$ no sample reached to the criteria defined by Pal et al. (1997) and Acedo (1997) (In Getinet at al. 2008) of about $10 \%$ of mass loss.

\section{Antioxidant Activity}

Natural antioxidants, present in fruits and vegetables, have gained increasing interest mostly by consumers due to epidemiological results indicating that high consumption of natural antioxidants is associated with lower risk of cardiovascular disease and cancer (Temple 2000). Tomatoes are considered a highly nutritious fruit due to their considerable concentration of vitamins $\mathrm{E}$ (tocopherols) and $\mathrm{C}$, lycopene, $\beta$-carotene (precursor of pro-vitamin $\mathrm{A}$ in the human body), fibres and phenolic compounds, namely flavonoids and phenolic acids (SotoZamora et al. 2005). 
Tomato antioxidants (AO) content is influenced by cultivar, maturity stage and applied analytical methodology (Cano et al. 2003; Raffo et al. 2002). In our study, an initial value of $599.4 \pm 29.4 \mu \mathrm{mol}$ Trolox $100 \mathrm{~g}^{-1}$ was determined for mature green 'Zinac' tomatoes. Lower values of antioxidant activity on cherry tomato ("Pomodoro di Pachino", 'Naomi' F1) were found by Raffo et al. (2006) at different harvesting time of the year $\left(<420 \mu\right.$ mol Trolox $\left.100 \mathrm{~g}^{-1}\right)$.

Only the AO content of TS samples $\left(518.2 \mu \mathrm{mol}\right.$ Trolox $\left.100 \mathrm{~g}^{-1}\right)$ differed significantly $(p<0.05)$ immediately after treatment. However, no significant differences between treatments were observed $(p<0.05)$. Tomato $\mathrm{AO}$ as affected by treatment during storage period at $10^{\circ} \mathrm{C}$ is shown in Fig. 5. Overall, after a decline during the first 4 days of storage, an increase of AO was observed until the end of storage: 16, 37, 30, 61 and $80 \%$ on TS, UV-C, US, Ctr and WHT, respectively. In our study, the intensity of UV-C applied $\left(0.97 \mathrm{~kJ} \mathrm{~m}^{-2}\right)$ promoted a lower AO value $(15 \%)$ than reported by Chang-hong et al. (2012), where UV-C treatment at $2 \mathrm{~kJ} \mathrm{~m}^{-2}$ induced an increase of $53 \%$ after 21 storage days.

\section{Total Phenolic Content}

Phenolic compounds are one of the major contributors to the antioxidant properties of fresh products (Gil et al. 2002) and are associated with anti-mutagenic and anticancer properties as well as with reduced cardiovascular diseases (Dillard and German 2000).

Untreated tomato showed an initial value of total phenolics (TPC) of $30.1 \pm 1.9 \mathrm{mg}$ GAE $100 \mathrm{~g}^{-1}$. The initial content of TPC of 'Zinac' tomato was higher than observed by Georgé et al. (2011) on red tomato (16.0 mg GAE $100 \mathrm{~g}^{-1}$ ) and Brat et al. (2006) (9.8-23.0 mg GAE $\left.100 \mathrm{~g}^{-1}\right)$. The differences between initial content of TPC could be due to maturity stage,

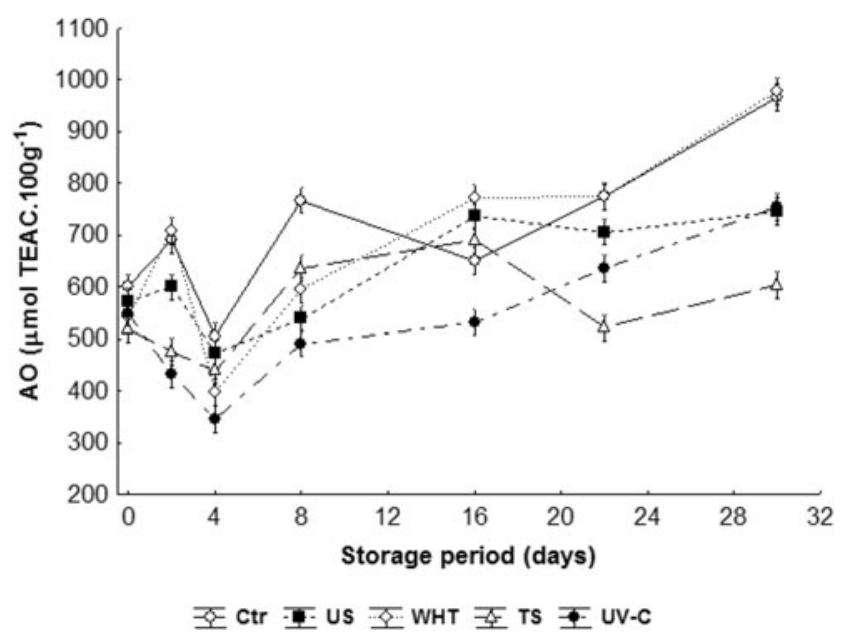

Fig. 5 Changes in antioxidant activity ( $\mu$ mol TEAC $100 \mathrm{~g}^{-1}$ ) of control (Ctr) and treated (US, WHT, TS, UV-C) stored tomato at $10^{\circ} \mathrm{C}$. Vertical bars represent $95 \%$ of confidence intervals cultivar or analytical methodology used. Macheix et al. (1990) showed that, in addition to genetic control, which is the main factor in determining phenolic compound accumulation in vegetable foods, external factors may also have a significant effect, such as UV radiation.

Immediately after treatment, and compared to Ctr samples, a TPC increase of $14 \%$ on US samples and reductions of 14 and $12 \%$ on WHT and TS samples, respectively, were observed. The reduction of TPC in WHT samples can be due to phenylalanine ammonia lyase (PAL) activity reduction. The application of heat treatments interrupts normal protein synthesis and reduces PAL accumulation and phenolic synthesis (Vicente et al. 2002).

The TPC content was lower for treated samples than control fruit, during almost all storage time. After 8 days of storage, a maximum of TPC was evident on Ctr samples (41.2 mg GAE $100 \mathrm{~g}^{-1}$ ), followed by a decline until the end of storage (Fig. 6). This behaviour has been also observed for antioxidant capacity (Fig. 5).

At the end of storage, a similar $(p>0.05)$ increase of TPC was detected on UV-C and TS treatments, reaching values of 39.4 and $35.7 \mathrm{mg} \mathrm{GAE} 100 \mathrm{~g}^{-1}$, respectively. Heat treatment and UV-C radiation have been associated with enhancement of bioactive compounds, such as vitamins, carotenoids and phenolic compounds in fruits and vegetables (Heredia and Cisneros-Zevallos 2009).

\section{Enzymatic Activity}

It is known that pectin methylesterase (PME: EC 3.1.1.11) is correlated with texture changes of fruits and vegetables. The generally high metabolic activity during ripening, results in higher PME activity and, consequently, greater solubilisation of pectin (Morais et al. 2008).

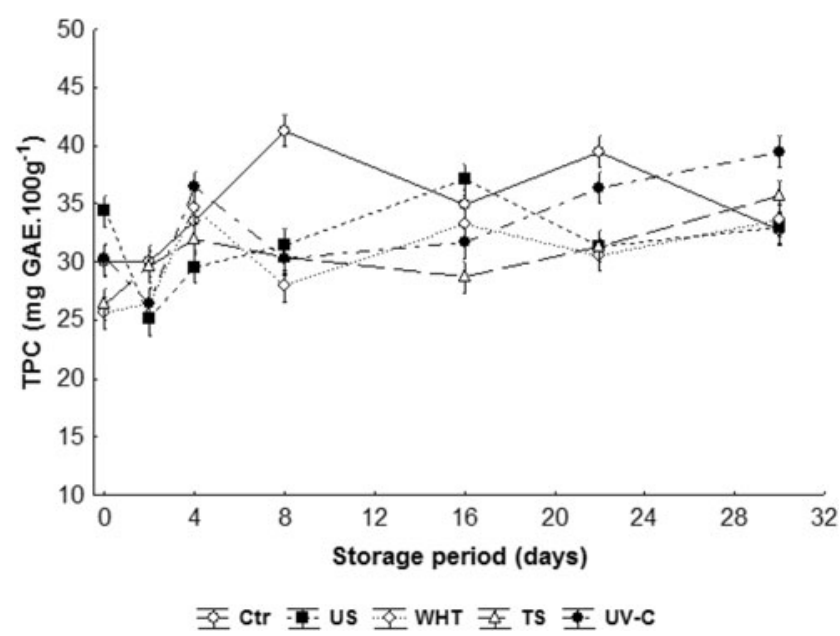

Fig. 6 Changes in total phenolic content (TPC, mg GAE $100 \mathrm{~g}^{-1}$ ) of control (Ctr) and treated (US, WHT, TS, UV-C) stored tomato at $10^{\circ} \mathrm{C}$. Vertical bars represent $95 \%$ of confidence intervals 
A significant $(p<0.05)$ decrease of PME activity, ca. $12.5 \%$ on US and UV-C samples and $25 \%$ on WHT and TS samples, was observed, compared to Ctr sample. Similar PME reduction was reported by Pombo et al. (2009) after processing strawberry with a higher intensity UV-C treatment $\left(4.1 \mathrm{~kJ} \mathrm{~m}^{-2}\right)$.

Figure 7a represents PME activity changes for control and treated tomato samples during storage at $10{ }^{\circ} \mathrm{C}$. In control samples, PME activity increased gradually ca. $25 \%$ until day 16 and then a slight decrease was observed. Previous works reported similar behaviour for PME activity, mostly in tropical fruits like sapodilla, guava, papaya and carambola (Morais et al. 2008; Miranda et al. 2002; Abu-Goukh and Bashir 2003; Ali et al. 2004).

PME activity was significantly $(p<0.05)$ lower in WHT, US and UV-C compared to control and TS samples. Similar $(p>0.05)$ PME activities were observed along storage period

(A)
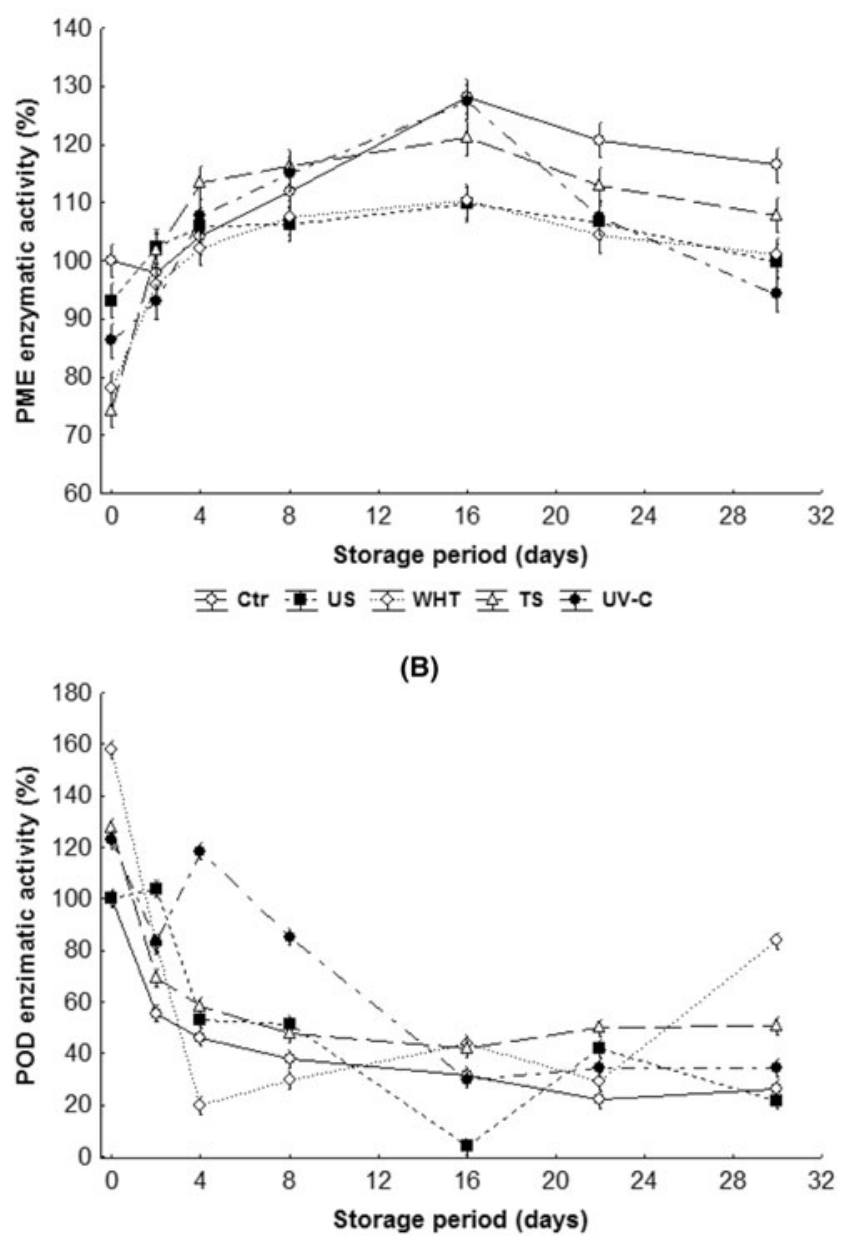

토 Ctr US 조 WHT 조 TS \$ UV-C

Fig. 7 Changes in enzymatic activity of pectin methylesterase (PME, \%) (a) and peroxidase (POD, \%) (b) of control (Ctr) and treated (US, WHT, TS, UV-C) stored tomato at $10{ }^{\circ} \mathrm{C}$. Vertical bars represent $95 \%$ of confidence intervals for WHT and US samples. The enzymatic activity found in UV-C, TS and WHT samples was logical and coherent with firmness value, where lower PME activity led to higher fruit firmness.

Quality changes related to enzymatic activity are also due to peroxidase (POD), which is responsible for several biochemical reactions, such as oxidation of many organic compounds, leading to product's flavour, colour and nutritional degradation (Thongsook and Barrett 2005).

A significant increase $(P<0.05)$ of POD activity, ca. 56, 26 and $22 \%$, was observed immediately after WHT, TS and UV$\mathrm{C}$, respectively, with exception of US. The increase of enzymatic activity was due to response of different types of stresses, both biotic and abiotic (Rivero et al. 2001).

POD activity (Fig. 7b) of all samples declined during storage. This was more pronounced until the 8th storage day on Ctr and TS samples, remaining constant until day 30 . At the end of storage, the WHT samples reach a value of $83 \%$, followed by TS (49\%), UV-C (34\%), Ctr (26\%) and US (22\%).

\section{Microbial Load}

Initial mesophilic counts of $5.2 \pm 0.2$ and $3.2 \pm 0.1 \log _{10}$ of Y\&M were found in fresh tomato at arrival to laboratory. After treatments, a reduction in all samples was detected. The conventional decontamination treatment (Ctr) provided a decrease of mesophyles and $\mathrm{Y} \& \mathrm{M}$, ca. 1.6 and $1.2 \log _{10}$ cycles, respectively, and is consistent with results obtained by Pinheiro et al. (2014) and Felkey et al (2006), where the maximum of microbial reduction achieved was less than $2.0 \log _{10}$. In this study, the reduction of initial microbial load of tomato fruit as a result of UV-C radiation $\left(0.97 \mathrm{~kJ} \mathrm{~m}^{-2}\right)$ was more efficient than previously obtained (Pinheiro et al. 2010), and this decrease maybe be attributed to a higher microbial load presented on the raw material. The germicidal effect of UV-C radiation can be attributed to photochemical lesion induced on microorganisms DNA and RNA, resulting in the inability to carry out normal transcription and replication of nucleic acids and normally, the cell dies (Bolton and Linden 2003; Unluturk et al. 2008).

TS treatment contributed to the highest decrease on mesophylic counts, immediately after UV-C radiation. This efficiency can result from the combination of physical and chemical processes, which occur during cavitation, i.e., the formation of pores outside the cell membrane, disruption of cell structures and breakage of cells as reported by Adekunte et al. (2010). On the other hand, singular effect of US did not conduct to an effective reduction on mesophylic count on whole tomato fruit.

The mesophylic and Y\&M of control and treated tomato fruit as affected by treatment and storage at $10{ }^{\circ} \mathrm{C}$ are 
Table 1 Microbial load: mesophyles and yeasts and moulds (average \pm standard deviation) of control (Ctr) and treated (US, WHT, TS and UV-C) tomato during 30 days of storage at $10^{\circ} \mathrm{C}$

\begin{tabular}{|c|c|c|c|}
\hline Samples & Storage period (days) & Mesophyles $\left(\log _{10}\left(\mathrm{cfu} \mathrm{g}^{-1}\right)\right)$ & $\mathrm{Y} \& \mathrm{M}\left(\log _{10}\left(\mathrm{cfu} \mathrm{g}^{-1}\right)\right)$ \\
\hline \multirow[t]{7}{*}{$\mathrm{Ctr}$} & 0 & $3.7^{\mathrm{k}, 1, \mathrm{~m}} \pm 0.1$ & $1.9^{\mathrm{h}, \mathrm{i}} \pm 0.1$ \\
\hline & 2 & $3.7^{\mathrm{k}, \mathrm{l,m}} \pm 0.1$ & $2.6^{1, \mathrm{~m}} \pm 0.1$ \\
\hline & 4 & $4.6^{\mathrm{n}, \mathrm{o}} \pm 0.4$ & $3.2^{\mathrm{n}} \pm 0.1$ \\
\hline & 8 & $5.9^{\mathrm{q}, \mathrm{r}} \pm 0.1$ & $3.7^{\mathrm{o}} \pm 0.1$ \\
\hline & 16 & $6.8^{\mathrm{s}, \mathrm{t}} \pm 0.4$ & $4.0^{\circ} \pm 0.1$ \\
\hline & 22 & $7.2^{t} \pm 0.1$ & $4.9^{\mathrm{p}} \pm 0.1$ \\
\hline & 30 & $7.1^{\mathrm{t}} \pm 0.1$ & $5.1^{\mathrm{p}} \pm 0.0$ \\
\hline \multirow[t]{7}{*}{ US } & 0 & $3.0^{\mathrm{j}, \mathrm{k}} \pm 0.1$ & $1.5^{\mathrm{c}, \mathrm{d}} \pm 0.1$ \\
\hline & 2 & $2.8^{\mathrm{h}, \mathrm{I}, \mathrm{j}, \mathrm{k}} \pm 0.1$ & $2.2^{\mathrm{f}, \mathrm{g}} \pm 0.2$ \\
\hline & 4 & $3.2^{\mathrm{j}, \mathrm{k}, 1} \pm 0.2$ & $2.6^{\mathrm{g}, \mathrm{h}} \pm 0.1$ \\
\hline & 8 & $4.7^{\mathrm{o}, \mathrm{p}} \pm 0.2$ & $2.9^{\mathrm{h}, \mathrm{i}} \pm 0.1$ \\
\hline & 16 & $5.2^{\mathrm{p}, \mathrm{q}} \pm 0.1$ & $3.6^{\mathrm{j}, 1, \mathrm{~m}} \pm 0.1$ \\
\hline & 22 & $5.7^{\mathrm{q}, \mathrm{r}} \pm 0.3$ & $3.9^{\mathrm{m}, \mathrm{n}} \pm 0.1$ \\
\hline & 30 & $6.1^{\mathrm{r}, \mathrm{s}} \pm 0.1$ & $4.2^{\mathrm{n}} \pm 0.1$ \\
\hline \multirow[t]{7}{*}{ WHT } & 0 & $2.2^{\mathrm{b}, \mathrm{c}, \mathrm{d}} \pm 0.1$ & $1.0^{\mathrm{a}} \pm 0.0$ \\
\hline & 2 & $2.5^{\mathrm{c}, \mathrm{d}} \pm 0.0$ & $1.0^{\mathrm{a}} \pm 0.0$ \\
\hline & 4 & $3.7^{\mathrm{f}, \mathrm{g}} \pm 0.2$ & $1.2^{\mathrm{a}, \mathrm{b}} \pm 0.1$ \\
\hline & 8 & $4.8^{\mathrm{h}, \mathrm{I}, \mathrm{j}, \mathrm{k}} \pm 0.0$ & $1.7^{\mathrm{c}} \pm 0.1$ \\
\hline & 16 & $5.2^{\mathrm{j}, \mathrm{k}, 1, \mathrm{~m}} \pm 0.0$ & $2.4^{\mathrm{e}, \mathrm{f}, \mathrm{g}} \pm 0.1$ \\
\hline & 22 & $5.8^{1, \mathrm{~m}, \mathrm{n}} \pm 0.1$ & $3.5^{\mathrm{i}, \mathrm{j}, 1} \pm 0.2$ \\
\hline & 30 & $5.9^{\mathrm{m}, \mathrm{n}} \pm 0.1$ & $3.6^{\mathrm{i}, \mathrm{j}, 1} \pm 0.1$ \\
\hline \multirow[t]{7}{*}{ TS } & 0 & $1.9^{\mathrm{a}, \mathrm{b}, \mathrm{c}} \pm 0.1$ & $1.5^{\mathrm{a}, \mathrm{b}} \pm 0.3$ \\
\hline & 2 & $2.0^{\mathrm{a}, \mathrm{b}, \mathrm{c}} \pm 0.1$ & $1.7^{\mathrm{c}} \pm 0.1$ \\
\hline & 4 & $2.2^{\mathrm{b}, \mathrm{c}, \mathrm{d}} \pm 0.3$ & $2.0^{\mathrm{c}, \mathrm{d}, \mathrm{e}} \pm 0.1$ \\
\hline & 8 & $3.4^{\mathrm{e}, \mathrm{f}} \pm 0.4$ & $2.6^{\mathrm{f}, \mathrm{g}} \pm 0.1$ \\
\hline & 16 & $3.8^{\mathrm{f}, \mathrm{g}} \pm 0.2$ & $2.8^{\mathrm{g}, \mathrm{h}} \pm 0.2$ \\
\hline & 22 & $3.8^{\mathrm{f}, \mathrm{g}} \pm 0.1$ & $3.2^{\mathrm{h}, \mathrm{i}} \pm 0.1$ \\
\hline & 30 & $4.2^{\mathrm{g}, \mathrm{h}} \pm 0.1$ & $3.5^{\mathrm{i}, \mathrm{j}, 1} \pm 0.1$ \\
\hline \multirow[t]{7}{*}{ UV-C } & 0 & $1.5^{\mathrm{a}} \pm 0.0$ & $1.0^{\mathrm{a}} \pm 0.1$ \\
\hline & 2 & $1.7^{\mathrm{a}, \mathrm{b}} \pm 0.1$ & $1.0^{\mathrm{a}} \pm 0.1$ \\
\hline & 4 & $2.7^{\mathrm{d}, \mathrm{e}} \pm 0.1$ & $1.2^{\mathrm{a}, \mathrm{b}} \pm 0.1$ \\
\hline & 8 & $3.6^{\mathrm{f}, \mathrm{g}} \pm 0.0$ & $1.6^{\mathrm{b}, \mathrm{c}} \pm 0.1$ \\
\hline & 16 & $4.2^{\mathrm{g}, \mathrm{h}, \mathrm{i}} \pm 0.1$ & $2.2^{\mathrm{d}, \mathrm{e}, \mathrm{f}} \pm 0.1$ \\
\hline & 22 & $4.7^{\mathrm{h}, \mathrm{I}, \mathrm{j}} \pm 0.1$ & $3.4^{\mathrm{i}, \mathrm{j}} \pm 0.1$ \\
\hline & 30 & $4.9^{\mathrm{i}, \mathrm{j}, \mathrm{k}} \pm 0.1$ & $3.5^{\mathrm{i}, \mathrm{j}, 1} \pm 0.1$ \\
\hline
\end{tabular}

Different letters in the same column indicated significant differences $(p<0.05)$

$\mathrm{Ctr}\left(150 \mathrm{ppm}\right.$ at $5{ }^{\circ} \mathrm{C}$, pH 6.5, $\left.2 \mathrm{~min}\right)$; US (45 kHz, $\left.80 \%, 30 \mathrm{~min}\right)$; WHT $\left(40{ }^{\circ} \mathrm{C}, 30 \mathrm{~min}\right)$, TS $\left(45 \mathrm{kHz}, 80 \%, 40{ }^{\circ} \mathrm{C}, 30 \mathrm{~min}\right)$ and UV-C $\left(0.97 \mathrm{~kJ} . \mathrm{m}^{-2}\right)$

shown in Table 1. Overall, during storage, a growth of mesophyles and Y\&M load in all samples was observed, and in the first 8 days of storage, the microbial load increased at a faster rate. According to the maximum value recommended (aerobic mesophilic flora $<5.1 \log _{10} \mathrm{cfu} \mathrm{g}^{-1}$ ) by the International Commission on Microbiological Specifications for Foods (ICMSF 1986), the TS- and UV-C-treated samples did not reach this limit during the study. So, a gain of 26 storage days at $10{ }^{\circ} \mathrm{C}$ was achieved in these samples, when compared with the control (Ctr).

\section{Conclusions}

The present study demonstrates that preservation technologies, when applied immediately after harvest, can ensure better fruit quality during postharvest period. The sensorial perception of colour and fruit firmness was not affected just after application of all treatments. At the end of storage, a better preservation of total phenol content and firmness, and lower water losses were achieved on UV-C-treated samples, and the microbial load was reduced significantly, when compared with standard chlorinated water solution. Therefore, UV-C 
treatment appears to be an effective, environmentally safe method that reduces water consumption and decay of tomato quality. This postharvest treatment may be considered for industrial use as a potential tool to deliver healthier whole tomato fruit and prolong its storage period, reducing fruit quality losses.

Acknowledgments The author Joaquina Pinheiro gratefully acknowledges her Ph. D. grant (SFRH/BD/24913/2005) to Fundação para a Ciência e a Tecnologia (FCT) from Ministério da Ciência e do Ensino Superior (Portugal). Moreover, the authors greatly acknowledge the technical assistance of Maria do Carmo and Ana Magalhães for helping in performing the microbial analysis. This work was supported by National Funds from FCT through project PEst-OE/EQB/LA0016/2011.

\section{References}

Abreu, M., Alegria, C., Gonçalves, E. M., Pinheiro, J., Moldão-Martins, M., \& Empis, J. (2011). Modelling of preheat treatment optimization applied to fresh-cut "Rocha" pear. Journal of Food Quality, 34(5), 315-326.

Abu-Goukh, A. B. A., \& Bashir, H. A. (2003). Changes in pectic enzymes and cellulase activity during guava fruit ripening. Food Chemistry, 83, 213-218.

Acedo, A. L. (1997). Storage life of vegetables in simple evaporative coolers. Tropical Science, 37, 169-175.

Adekunte, A. O., Tiwari, B. K., Cullen, P. J., Scannell, A. G. M., \& O'Donnell, C. P. (2010). Effect of sonication on colour, ascorbic acid and yeast inactivation in tomato juice. Food Chemistry, $122(3), 500-507$.

Alexandre, E. M. C., Santos-Pedro, D. M., Brandão, T. R. S., \& Silva, C. L. M. (2011). Study on thermosonication and ultraviolet radiation processes as an alternative to blanching for some fruits and vegetables. Food Bioprocess Technology, 4, 1012-1019.

Ali, Z. M., Chin, L. H., \& Lazan, H. A. (2004). Comparative study on wall degrading enzymes, pectin modifications and softening during ripening of selected tropical fruits. Plant Science, 167, 317-327.

Alia-Tejacal, I., Villanueva-Arce, R., Pelayo-Zaldívar, C., Colinas-Léon, M. T., López-Martínez, V., \& Bautista-Baños, S. (2007). Postharvest physiology and technology of sapote mamey fruit (Pouteria sapota (jacq.) H.E. Moore \& Stearn). Postharvest Biology and Technology, 45, 285-297.

Assi, N. M. E. (2004). Alleviating chilling injury and maintaining quality of tomato fruit by hot water treatment. Emirates Journal of Agricultural Science,16(1), 1-7.

Barka, E. A., Kalantari, S., Malhlouf, J., \& Arul, J. (2000). Impact of UV$\mathrm{C}$ irradiation on the cell wall-degrading enzymes during ripening of tomato (Lycopersicon esculentum L.) fruit. Journal of Agricultural and Food Chemistry, 48, 667-671.

Barka, M., Mercier, J., Corcuff, R., Castaigne, F., \& Arul, J. (1999). Photochemical treatment to improve storability of fresh strawberries. Journal of Food Science, 64, 1068-1072.

Bartz, J. A., Eayre, C. G., Mahovic, M. J., Concelmo, D. E., Brecht, J. K., $\&$ Sargent, S. A. (2001). Chlorine concentration and the inoculation of tomato fruit in packinghouse dump tanks. Plant disease, 85, 885889.

Bolton, J. R., \& Linden, K. G. (2003). Standardization of methods for fluence (UV dose) determination in bench-scale UV experiments. Journal of Environmental Engineering, 129, 209-215.

Brat, P., Georgé, S., Bellanmy, A., Chaffaut, L. D., Scalbert, A., \& Mennen, L. (2006). Daily polyphenol intake in France from fruits and vegetables. Journal of Nutrition, 136, 2368-2373.
Brodl, M. R. (1989). Regulation of the synthesis of normal cellular proteins during heat shock. Physiology Plant, 75, 439-443.

Cano, A., Acosta, M., \& Arnao, M. (2003). Hydrophilic and lipophilic antioxidant activity changes during on-vine ripening of tomatoes (Lycopersicon esculentum Mill.). Postharvest Biology and Technology, 28, 59-65.

Chang-hong, L., Lu-yun, C., Xian-ying, L., Xiao-xu, H., \& Tie-jin, Y. (2012). Effect of postharvest UV-C irradiation on phenolic compound content and antioxidant activity of tomato fruit during storage. Agricultural Sciences in China, 11(1), 159-165.

Dávila-Aviña, J. E. J., Villa-Rodríguez, J., Cruz-Valenzuela, R., Rodríguez-Armenta, M., Espino-Díaz, M., Ayala-Zavala, J. F., et al. (2011). Effect of edible coatings, storage time and maturity stage on overall quality of tomato fruits. American Journal of Agricultural and Biological Sciences, 6(1), 162-171.

Dillard, C., \& German, B. (2000). Phytochemicals: nutraceuticals and human health. Journal of the Science of Food and Agriculture, 80, 1744-1756.

Felkey, K., Archer, D. L., Bartz, J. A., Goodrich, R. M., \& Schneider, K. A. (2006). Chlorine disinfection of tomato surface wounds contaminated with Salmonella spp. Hortechnology, 16(2), 253-256.

Forney, C. F. (1995). Hot-water dips extend the shelf life of fresh broccoli. Hortscience, 30(5), 1054-1057.

Georgé, S., Tourniaire, F., Gautier, H., Goupy, P., Rock, E., \& CarisVeyrat, C. (2011). Changes in the contents of carotenoids, phenolic compounds and vitamin $\mathrm{C}$ during technical processing and lyophilisation of red and yellow tomatoes. Food Chemistry, 124, $1603-1611$.

Getinet, H., Seymour, T., \& Woldetsadik, K. (2008). The effect of cultivar, maturity stage and storage environment on quality of tomatoes. Journal of Food Engineering, 87, 467-478.

Gil, M., Tomas-Barberan, F., Hess-Pierce, B., \& Kader, A. (2002). Antioxidant capacities, phenolic compounds, carotenoids, and vitamin $\mathrm{C}$ contents of nectarines, peach, and plum cultivars from California. Journal of Agricultural and Food Chemistry, 50, 4976-4982.

Guillén, F., Castillo, S., Zapata, P. J., Martínez-Romero, D., Valero, D., \& Serrano, M. (2006). Efficacy of 1-MCP treatment in tomato fruit. 2 -Effect of cultivar and ripening stage at harvest. Postharvest Biology and Technology, 42, 235-242.

Heredia, J. B., \& Cisneros-Zevallos, L. (2009). The effect of exogenous ethylene and methyl jasmonate on pal activity, phenolic profiles and antioxidant capacity of carrots (Daucus carota) under different wounding intensities. Postharvest Biology and Technology, 51(2), 242-249.

ICMSF (1986). Microorganisms in Foods 2. Sampling for microbiological analysis: principles and specific applications (2nd Edition), Blackwell Scientific Publications. Toronto: University of Toronto Press. http://www.icmsf.org/pdf/icmsf2.pdf. Accessed 2 May 2013.

ISO 13299 (1995). Sensory analysis - Methodology — General guidance for establishing a sensory profile.

ISO 4833 (2003). Microbiology of food and animal feeding stuffsHorizontal method for the enumeration of microorganismsColony-count technique at $30{ }^{\circ} \mathrm{C}$.

ISO 8586-1 (1993). Sensory analysis - General guidance for the selection, training and monitoring of assessors.

Klee, H. J., \& Giovannoni, J. J. (2011). Genetics and control of tomato fruit ripening and quality attributes. Annual Review of Genetics, 45, 41-59.

Macheix, J. J., Fleuriet, A., \& Billot, J. (1990). Changes and metabolism of phenolic compounds in fruits. In Fruit Phenolics (pp. 149-221). Boca Raton, FL: CRC Press.

Mari, M., Guizzardi, M., Brunelli, M., \& Folchi, A. (1996). Postharvest biological control of grey mould (Botrytis cinerea Pers.: Fr.) on fresh-market tomatoes with Bacillus amyloliquefaciens. Crop Protection, 15(8), 699-705. 
Mathooko, F. M. (2003). A comparative study of the response of tomato fruit to low temperature storage and modified atmosphere packaging. African Journal of Food, Agriculture, Nutrition and Development, 2, 34-41.

Miranda, M. R. A., Silva, F. S., Figueiras, H. A. C., Alves, R. E. \& Aráujo, N. C. C. (2002). Enzymes and pectin breakdown of sapodilla during modified atmosphere storage. Proceedings of the Interamerican Society for Tropical Horticulture, 45, 18-21.

Morais, P. L. D., Lima, L. C. O., Miranda, M. R. A., Alves, R. E., \& Silva, J. D. (2008). Enzyme activities and pectin breakdown of sapodilla submitted to 1-methylcyclopropene. Pesquisa Agropecuária Brasileira, 43(1), 15-20.

NP 3277 (1987). Microbiologia alimentar. Contagem de bolores e leveduras. Parte 1: Incubação a $37^{\circ} \mathrm{C}$.

Pal, R. K., Roy, S. K., \& Srivastava, S. S. (1997). Storage performance of Kinnow mandarins in evaporative cool chamber and ambient conditions. Journal of Food Science and Technology, 34(3), 200-203.

Pan, J., Vicente, A. R., Martinez, G. A., Chavez, A. R., \& Civello, P. M. (2004). Combined use of UV-C irradiation and heat treatment to improve postharvest life of strawberry fruit. Journal of Food Science and Agriculture, 84, 1831-1838.

Pinheiro, J., Alegria, C., Abreu, M., Gonçalves, E. M. \& Silva, C. L. M. (2012d). Optimization, heat stability and kinetic characterization of pectin methyl esterase enzyme from tomato (Solanum lycopersicum 'Zinac') fruits. In: Editors Marita Cantwell and Domingos Almeida, Acta Horticulturae (ISHS- International Society for Horticultural Science) 934, 1283-1290.

Pinheiro, J., Alegria, C., Abreu, M., Gonçalves, E. M., \& Silva, C. L. M. (2013). Kinetics of changes in the physical quality parameters of fresh tomato fruits (Solanum lycopersicum, cv. 'Zinac') during storage. Journal of Food Engineering, 114, 338-345.

Pinheiro, J., Alegria, C., Abreu, M., Gonçalves, E. M. \& Silva, C. L. M. (2012c). Efeito da termossonicação na qualidade de tomate (Solanum Lycopersicum, cv. 'Zinac') inteiro. Proceedings of the conference: $11^{\circ}$ Encontro de Quimica dos Alimentos, Bragança, Portugal, 16 to 19 September:

Pinheiro, J., Alegria, C., Abreu, M., Sol, M., Gonçalves, E. M. \& Silva, C. L. M. (2012a). Impact of water heat treatment on physical-chemical, biochemical and microbiological quality of whole tomato (Solanum Lycopersicum) fruit. In: Editors Marita Cantwell and Domingos Almeida, Acta Horticulturae (ISHS-International Society for Horticultural Science) 934, 1269-1276.

Pinheiro, J., Alegria, C., Abreu, M., Sol, M., Gonçalves, E. M. \& Silva, C. L. M. (2010). Impact of UV-C radiation on tomato (Lycopersicum esculentum L., 'Zinac') quality and microbial load during refrigeration storage. Proceedings of First International Conference on Food Innovation 2010 (FOODINNOVA 2010), Valencia, Spain, 25-29 October.

Pinheiro, J., Alegria, C., Abreu, M., Sol, M., Gonçalves, E. M. \& Silva,. C. L. M. (2014). Postharvest quality of refrigerated tomato fruit (Solanum lycopersicum, 'Zinac') at two maturity stages following heat treatment. Journal of Food Processing and Preservation. doi:10. 1111/jfpp. 12279.

Pinheiro, J., Alegria, C., Abreu, M., Sol, M., Gonçalves, E. M. \& Silva, C. L. M. (2012b) Optimization of ultrasounds preservation treatment applied to whole tomato (Solanum lycopersicum, 'Zinac')". Proceedings of the conference: $16^{\text {th }}$ World Congress of Food Science and Technology: "Addressing Global Food Security and Wellness through Food Science and Technology", Foz do Iguaçu, Parana, Brazil, 5 to 9 August.

Pombo, M. A., Dotto, M. C., Martínez, C. A., \& Civello, P. M. (2009). UV-C irradiation delays strawberry fruit softening and modifies the expression of genes involved in cell wall degradation. Postharvest Biology and Technology, 51, 141-148.

Raffo, A., Leonardi, C., Fogliano, V., Ambrosino, P., Salucci, M., Gennaro, L., et al. (2002). Nutritional value of cherry tomatoes (Lycopersicon esculentum Cv. Naomi F1) harvested at different ripening stages. Journal of Agricultural and Food Chemistry, 50, $6550-6556$.

Raffo, A., Malfa, G. L., Fogliano, V., Maiania, G., \& Quaglia, G. (2006). Seasonal variations in antioxidant components of cherry tomatoes (Lycopersicon esculentum cv. Naomi F1). Journal of Food Composition and Analysis, 19, 11-19.

Re, R., Pellegrini, N., Proteggente, A., Pannala, A., Yang, M., \& RiceEvans, C. (1999). Antioxidant activity applying an improved ABTS radical cation decolorization assay. Free Radical Biology \& Medicine, 26(9-10), 1231-1237.

Rivero, R. M., Ruiz, J. M., García, P. C., López-Lefebre, L. R., Sánchez, E., \& Romero, L. (2001). Resistance to cold and heat stress: accumulation of phenolic compounds in tomato and watermelon plants. Plant Science, 160, 315-321.

Saltveit, M. E. (2005). Influence of heat shocks on the kinetics of chillinginduced ion leakage from tomato pericarp discs. Postharvest Biology and Technology, 36, 87-92.

Singleton, V. L., \& Rossi, J. A. (1965). Colorimetry of total phenolics with phosphomolybdic-phosphotungstic acid reagents. American Journal of Enology and Viticulture, 16(3), 144-158.

Soto-Zamora, G., Yahia, E. M., Brecht, J. K., \& Gardea, A. (2005). Effects of postharvest hot air treatments on the quality and antioxidant levels in tomato fruit. LWT - Food Science and Technology, $38(6), 657-663$.

StatSoft Inc (2004). STATISTICA (data analysis software system), version 7. www.statsoft.com.

Su, H., \& Glubber, W. D. (2012). Effect of 1-methylcyclopropene (1$\mathrm{MCP}$ ) on reducing postharvest decay in tomatoes (Solanum lycopersicum L.). Postharvest Biology and Technology, 64(1), 133-137.

Temple, N. J. (2000). Antioxidants and disease: more questions than answers. Nutrition Research, 20, 449-459.

Thongsook, T., \& Barrett, D. M. (2005). Heat inactivation and reactivation of broccoli peroxidase. Journal of Agricultural and Food Chemistry, 53, 3215-3222.

Unluturk, S., Atllgan, M. R., Handan, B. A., \& Tari, C. (2008). Use of UV-C radiation as a non-thermal process for liquid egg products (LEP). Journal of Food Engineering, 85(4), 561-568.

USDA. (1991). United States standard for grades of fresh tomatoes. United States Department of Agriculture. Washington DC, USDA: Agricultural Marketing Service.

Van Dijk, C., Boeriu, C., Peter, F., Stolle-Smits, T., \& Tijsken, L. M. M. (2006). The firmness of stored tomatoes (cv. Tradiro). 1. Kinetic and near infrared models to describe firmness and moisture loss. Journal of Food Engineering, 77, 575-584.

Vicente, A. R., Martínez, G. A., Civello, P. M., \& Chaves, A. R. (2002). Quality of heat-treated strawberry fruit during refrigerated storage. Postharvest Biology and Technology, 25, 59-71.

Vicente, A. R., Peneda, C., Lemoine, L., Civello, P. M., Martinez, G. A., \& Chaves, A. R. (2005). UV-C treatments reduce decay, retain quality and alleviate chilling injury in pepper. Postharvest Biology Technology, 35, 69-78.

Wills, R. B. H., Tirmazi, S. I. H., \& Scott, K. J. (1977). Use of calcium to delay ripening of tomatoes. HortScience, 12, 551-552.

Yahia, E. M., Soto-Zamora, G., Brecht, J. K., \& Gardea, A. (2007). Postharvest hot air treatment effects on the antioxidant system in stored mature-green tomatoes. Postharvest Biology and Technology, 44, 107-115. 